ISA

Arboriculture \& Urban Forestry 2016. 42(4): 217-226

\title{
Frequency, Severity, and Detectability of Internal Trunk Decay of Street Tree Quercus spp. in Tampa, Florida, U.S.
}

\author{
Andrew K. Koeser, Drew C. McLean, Gitta Hasing, and R. Bruce Allison
}

\begin{abstract}
Wood decay is a factor considered in all commonly accepted tree risk assessment methods; however, few studies have attempted to assess its presence in the urban forest or its predictability given visual cues and site factors. A random sampling of trees situated on hurricane evacuation routes was inventoried and assessed for risk in the city of Tampa, Florida, U.S. In addition to a basic visual assessment, a sampling of larger diameter $(>30.5 \mathrm{~cm})$ live oak (Quercus virginiana) and all large diameter laurel oak (Quercus laurifolia) trees were tested with a resistance-recording drill to determine the amount of decay present (looking specifically at the sound-wood-to-stem-diameter ratio). Overall, 56.9\% of the trees tested had some level of decay, though the incidence of decay was higher in laurel oak (67.4\%) than in the live oak (29.4\%). Additionally, tree species $(P<0.01)$, diameter $(P<0.01)$, and the presence or absence of visual decay indicators $(P=0.03)$ were all significant predictors of decay presence.

Key Words. Advanced Assessment; Basic Assessment; Decay Incidence; Decay Severity; Florida; Laurel Oak; Live Oak; Quercus laurifolia; Quercus virginiana; Risk Assessment; Tampa; Visual Risk Assessment.
\end{abstract}

Wood decay is a key defect that factors into the final ratings of most commonly accepted tree assessment methods (Matheny and Clark 1994; Pokorny et al. 2003; Ellison 2005; Johnstone et al. 2010a; Smiley 2011). As wood decays, the strength of the wood is reduced, and the likelihood of failure is increased. This is especially true if the decay is present at the outer edges of the trunk or stem, as the newest layers of wood experience the greatest torsional, compressive, and tension stress (Dunster et al. 2013; Ciftci et al. 2014). Visual assessments of advanced decay can be performed by noting cavities or changes in wood color and texture; however, the incipient stages of decay are not detectable visually or with simple tools (e.g., sounding hammer, increment borer). During these early stages of decay, the wood may appear normal, with little color or textural changes, yet the strength of the wood may still be significantly reduced (Wilcox 1978). To add to the problem, decay is sometimes completely internalized, with few outside signs or symptoms present to indicate the true impacts to potential tree risk (Kennard et al. 1996).
More precise tools have been developed to help quantify the extent of internal wood decay and help estimate the associated strength loss. In particular, resistance-recording drills and sonic tomography have been tested by numerous researchers (Rinn et al. 1996; Costello et al. 1999; Gilbert and Smiley 2004; Johnstone et al. 2007; Wang and Allison 2008; Johnstone et al. 2010a; Johnstone et al. 2010b; Arciniegas et al. 2014). While shown to be effective, these tools are often beyond the financial means of practitioners and require additional user expertise. Decay-detection devices also require calibration for the tree species of interest to help develop typical species/wood type profiles before results can be interpreted accurately (Mattheck et al. 1997). This process may involve an adjustment of equipment settings, or it may simply be a visual training process to recognize patterns in the output. Even if sufficiently equipped and trained, an arborist should consider the value of a given tree to a homeowner or community before recommending a more 
costly and time-consuming advanced assessment method (Smiley et al. 2011; Dunster et al. 2013).

Few studies in arboriculture and urban forestry have used advanced risk assessment techniques to assess decay levels in urban street tree populations. Two notable exceptions to this trend include a largescale study in upstate New York, U.S., where the researchers employed a resistance-recording drill to assess urban tree decay in commonly planted tree species (Luley et al. 2009), and an earlier assessment of decay in Central Park (New York, U.S.) trees using an increment borer (Tate 1984; Tate 1986). The authors of the more recent study found internal decay in nearly $60 \%$ of all the trees assessed (Luley et al. 2009). Of these, 3.2\% of trees had severe decay (defined by the authors as a tree with over $70 \%$ of the trunk radius decayed). And while large-diameter trees only accounted for a small proportion of the total population, they were the most likely to exhibit severe levels of decay (more than $70 \%$ of trunk radius decayed). Tate (1986) noted a lower overall decay frequency in his final results (14.4\%); however, his methods included both smaller trees (i.e., minimum diameter of $15.25 \mathrm{~cm}$ versus minimum diameter of 30.5) and fewer measurements per tree (i.e., one versus three) than the work by Luley et al. (2009). Tate (1984) also noted that decay severity increased with tree diameter.

No comparative work has been conducted on Quercus virginiana (live oak) and Quercus laurifolia (laurel oak), which are two species common to urban forests in subtropical Florida, U.S. Replicating and adding to the past work of Luley et al. (2009), this research offers an in-depth assessment of the internal decay associated with common Florida street trees and serves as a first step in modeling the relationship between visual decay indicators/environmental factors and the presence of internal decay. The objectives of the study were to: 1) assess the frequency and severity of internal decay in urban street trees in Tampa, Florida, U.S., and 2) identify and model site- and tree-related factors that are linked to the presence of decay and/or level of decay observed.

\section{MATERIALS AND METHODS}

\section{Sampling and Measurements}

This study was conducted on urban street trees located along designated hurricane priority response routes within the City of Tampa, Florida $\left(27.9710^{\circ} \mathrm{N}, 82.4650^{\circ} \mathrm{W}\right.$, USDA plant hardiness zones $9 \mathrm{~b} / 10 \mathrm{a})$. A random, 5\% sample of evacuation route street segments was selected using the i-Tree Storm sampling protocol (USDA Forest Service 2014) and a geographic information system platform (ArcGIS, ESRI, Redlands, California, U.S.). All trees located within the rights-of-way of the sample segments were inventoried and visually assessed for risk using the USDA Forest Service Community Tree Evaluation Form (Pokorny 2003). All risk assessments were conducted by the same International Society of Arboriculture (ISA) Certified Arborist ${ }^{\circledR}$ holding the ISA Tree Risk Assessment Qualification. The inventory and risk-assessment factors assessed are summarized in Table 1.

Table 1. Variables evaluated for inclusion in initial multivariate logistic regression model to predict the presence and absence of decay.

\begin{tabular}{llc}
\hline Variable & Definition & Mean/Count (Std. Dev.) \\
\hline Species-live oak & Tree is a Q. virginiana (as compared to Q. laurifolia base level) & $153(\mathrm{n} / \mathrm{a})$ \\
Tree diameter & Diameter at breast height for tree in centimeters & $59.5(27.3)$ \\
Planting width & Width of planting site in meters & $5.6(2.8)$ \\
Visual decay & Presence of visual decay indicators anywhere on tree & $64(\mathrm{n} / \mathrm{a})$ \\
Visual root problems & Presence of root problems ${ }^{\mathrm{z}}$ & $47(\mathrm{n} / \mathrm{a})$ \\
Visual weak branch union & Presence of weak branch union ${ }^{z}$ & $202(\mathrm{n} / \mathrm{a})$ \\
Visual dead & Presence of dead wood anywhere on tree & $111(\mathrm{n} / \mathrm{a})$ \\
Sidewalk conflict & Presence of sidewalk damage within three meters of tree & $12(\mathrm{n} / \mathrm{a})$ \\
Powerline conflict & Presence of overhead utilities (directly overhead or within three meters) & $44(\mathrm{n} / \mathrm{a})$
\end{tabular}

${ }^{2}$ As specified in Pokorny (2003). 
Within the sampled evacuation routes, all laurel oak and a portion of the live oak (sample size calculated to provide a confidence interval of 5 at a $95 \%$ confidence level) over $30.5 \mathrm{~cm}$ in diameter at $1.3 \mathrm{~m}$ from the ground were assessed for internal decay using a resistance-recording drill with a $50.8 \mathrm{~cm}$ needle (Resistograph F500-S, IML GmbH, Wiesloch, Germany). Each tree was drilled three times with the resistance-recording drill, with the second and third measurements made 120 degrees off each side of the initial measurement point. Measurements were made deep enough to reach the center of the trunk when possible. All measurements were made 0.3 to $1.5 \mathrm{~m}$ above the base of the tree along the main trunk. If present, visual indicators of decay were used to guide the initial measurement. If no visual decay indicator(s) was present, the tree was sampled for decay at breast height with the first measurement made on the north side of the tree. Physical records of the measurements were collected on wax paper charts, though actual data analysis was conducted on electronic data exported from the resistancerecording drill and manipulated with a resistance profile viewing application (F-Tools Pro, v.1.9, IML System GmbH, Wiesloch, Germany). In following, the decision rule used by Luley et al. (2009), a drop in drilling resistance over $13 \mathrm{~mm}$ long was interpreted as the indication of decay.

The decay detection protocol used for this study was modeled after the methods documented by Luley et al. (2009) in an effort to facilitate a meaningful comparison. In replicating these methods, two key exceptions were made: 1) maximum measurement height (along the trunk) and 2) maximum drilling depth. The equipment used in the current study offered an additional $12 \mathrm{~cm}$ of measurement depth compared to Luley et al. (2009). This additional drilling range also increased the size and weight of the equipment. Given this, all measurements were made from the ground, providing researchers with a maximum measurement height of $1.5 \mathrm{~m}$ as compared to the $3.1 \mathrm{~m}$ range used in the previous study (Luley et. al. 2009). Additionally, Luley et al. (2009) used a mallet to sound trunks when locating initial measurement points. This technique was not employed for the current study.

\section{Data Analysis}

In addition to general summary statistics, kernel density plots for the diameter at breast height ( $\mathrm{dbh}$ ) and sound-wood-to-stem-radius ratio distributions were generated using the sm.density.compare() function in $\mathrm{R}$ (Bowman and Azzalini 2014). This function provided both a visual comparison and a bootstrap hypothesis test of overall distribution equality for these two measured factors across species (Bowman and Azzalini 2014). The sm.density. compare() function was also used to generate a band (based on the null model of no difference between the two distributions) to indicate which regions along the frequency two distributions were likely to be the cause of any significant difference between the live oak and laurel oak (Langlois et al. 2012).

Additionally, logistic regression was used to model factors associated with the presence or absence of internal decay using the $\operatorname{glm}()$ function in $\mathrm{R}$ ( $\mathrm{R}$ Development Core Team 2014). Trees were categorized as "decayed" if their ratio of sound wood to stem radius was less than 1.00 (regardless of level). A backand-forth Akaike information criterion-based (AIC-based) stepwise deletion function was run as a coarse filter to remove non-significant factors and interactions (Sheather 2010). Further model simplification was conducted to remove a remaining, non-significant factor (i.e., weak branch attachment). This final model was compared against its predecessor, using the anova() function in $\mathrm{R}$ to confirm the change in residual sums of squares was not significant (Crawley 2013).

Marginal model plots were produced via the mmps() function in $\mathrm{R}$ and used to diagnosis model validity (Fox and Weisberg 2011). These plots showed the inclusion of quadratic and cubic terms for diameter at breast height was required to improve fit. Finally, standardized deviance values and leverage values were plotted for each observation to determine if any outliers were unduly influencing the model (Sheather 2010). Finding none, the final, minimally adequate model was set (Table 2). All decisions for the aforementioned analyses were made at an $\alpha=0.05$ level of type 1 error. 
Table 2. Final model and regression results for factors contributing to the presence and absence of decay in live ( $Q$. virginiana) and laurel (Q. laurifolia) oak street trees in Tampa, Florida, U.S.

\begin{tabular}{|c|c|c|c|c|c|c|}
\hline Variable & Coefficient & Standard error & $P$-value & Odds ratio & 95\% CI lower & 95\% CI upper \\
\hline Intercept & -9.4998 & 2.4854 & 0.0001 & -- & -14.8845 & -4.8744 \\
\hline Visual decay & 0.8511 & 0.3944 & 0.0309 & $2.3422(\mathrm{D})^{\mathrm{z}}$ & 0.0835 & 1.6374 \\
\hline Species-live oak & -1.8477 & 0.3672 & 0.0012 & $6.3452(\mathrm{~S})$ & -1.9162 & -0.4707 \\
\hline Tree diameter & 0.3394 & 0.0977 & 0.0005 & 1.4041 (D) & 0.1592 & 0.5581 \\
\hline Tree diameter ${ }^{2}$ & -0.0034 & 0.0012 & 0.0036 & $1.0034(\mathrm{~S})$ & -0.0062 & -0.0013 \\
\hline Tree diameter $^{3}$ & $1.1060 \times 10^{-5}$ & $4.3750 \times 10^{-6}$ & 0.0114 & $<1.0001(\mathrm{D})$ & $3.3932 \times 10^{-6}$ & $2.1927 \times 10^{-5}$ \\
\hline
\end{tabular}

${ }^{z}$ Positive coefficients indicate an increased likelihood of decay (D). Negative coefficients indicate an increased likelihood of sound wood (S). Odds ratios have been added for ease in interpretation. For example, a live oak tree is more than six times more likely to be completely sound than a laurel oak. For the three tree diameter predictor variables, likelihood of decay increases/decreases with each centimeter diameter is increased.

\section{RESULTS AND DISCUSSION}

\section{Trees Sampled}

In all, 374 live oak, and 110 laurel oak trees were sampled and assessed for risk along the hurricane evacuation route segments. Live oak was the most abundant species inventoried along the sample route (Figure 1). Excluding palms, laurel oak was the second most abundant species (Figure 1). Average dbh did not differ significantly by species $(P=0.55)$. Mean diameter at breast height for live and laurel oak was $58.7 \mathrm{~cm}( \pm 2.4)$ and $60.8 \mathrm{~cm}( \pm 2.4)$, respectively. However, when kernel density plots were used to assess the distribu- tions as a whole (and not just a single summary statistic), there were detectable differences in the measured diameters for the two species $(P=0.01$, Figure 2). Live oak tended to have more individuals with stems 25 to $45 \mathrm{~cm}$ in diameter (Figure $2)$. Conversely, laurel oak had more individuals with stems 60 to $75 \mathrm{~cm}$ in diameter (Figure 2).

The maximum diameters recorded were 137.2 $\mathrm{cm}$ for laurel oak and $174.5 \mathrm{~cm}$ for live oak. As such, despite the increased measurement range of the drilling equipment $(50.8 \mathrm{~cm})$, researchers had the same limitation noted by Luley et. al. (2009) in that they were unable to fully measure decay levels to the center of the largest trees.

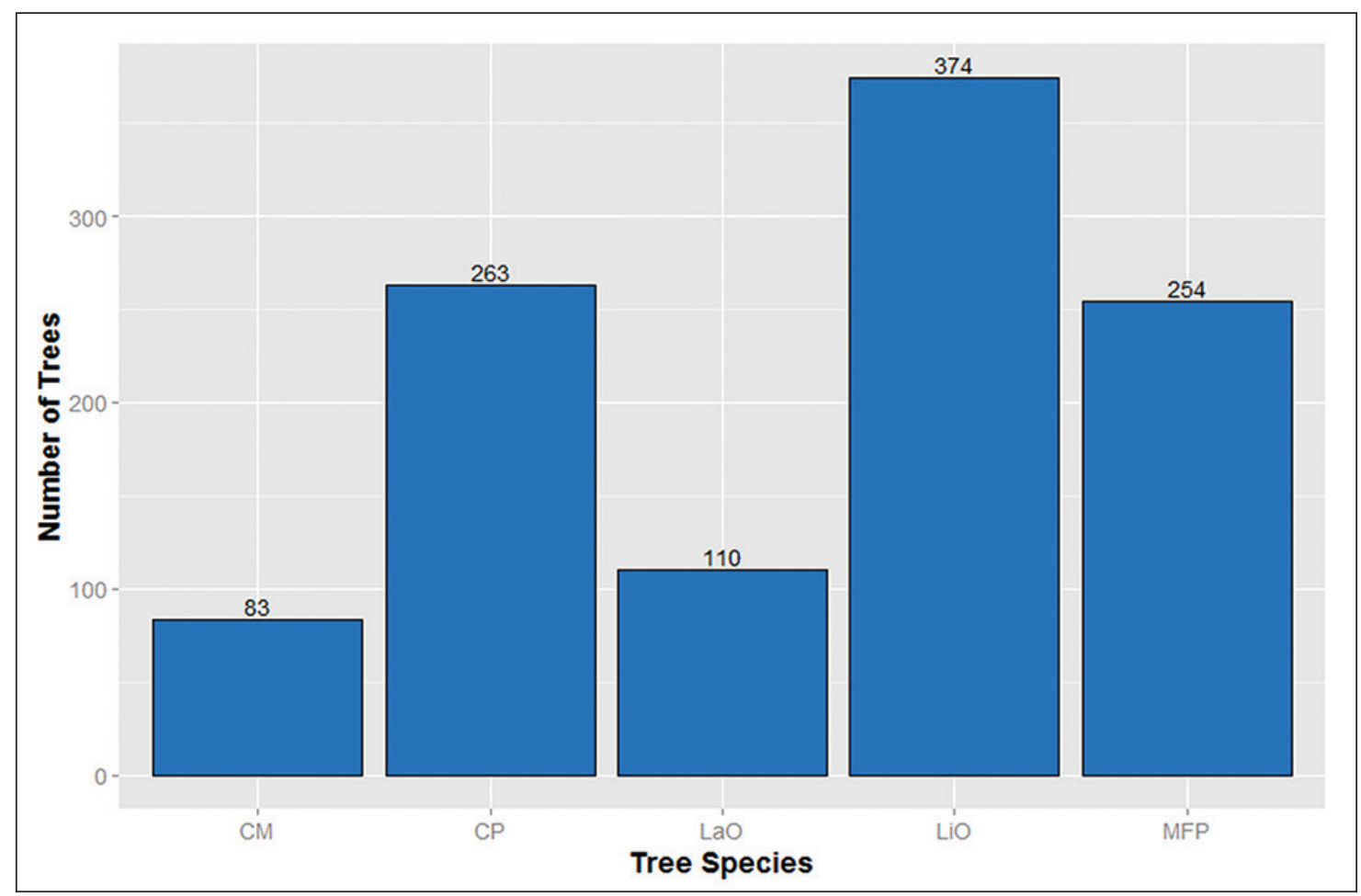

Figure 1. Top five species inventoried along the sampled hurricane evacuation routes in Tampa, Florida, U.S. Species are as follows: $\mathrm{CM}=$ crapemyrtle (Lagerstroemia indica); $\mathrm{CP}=$ cabbage palm (Sabal palmetto); LaO = laurel oak (Quercus laurifolia); LiO = live oak (Quercus virginiana); MFP = Mexican fan palm (Washingtonia robusta). 


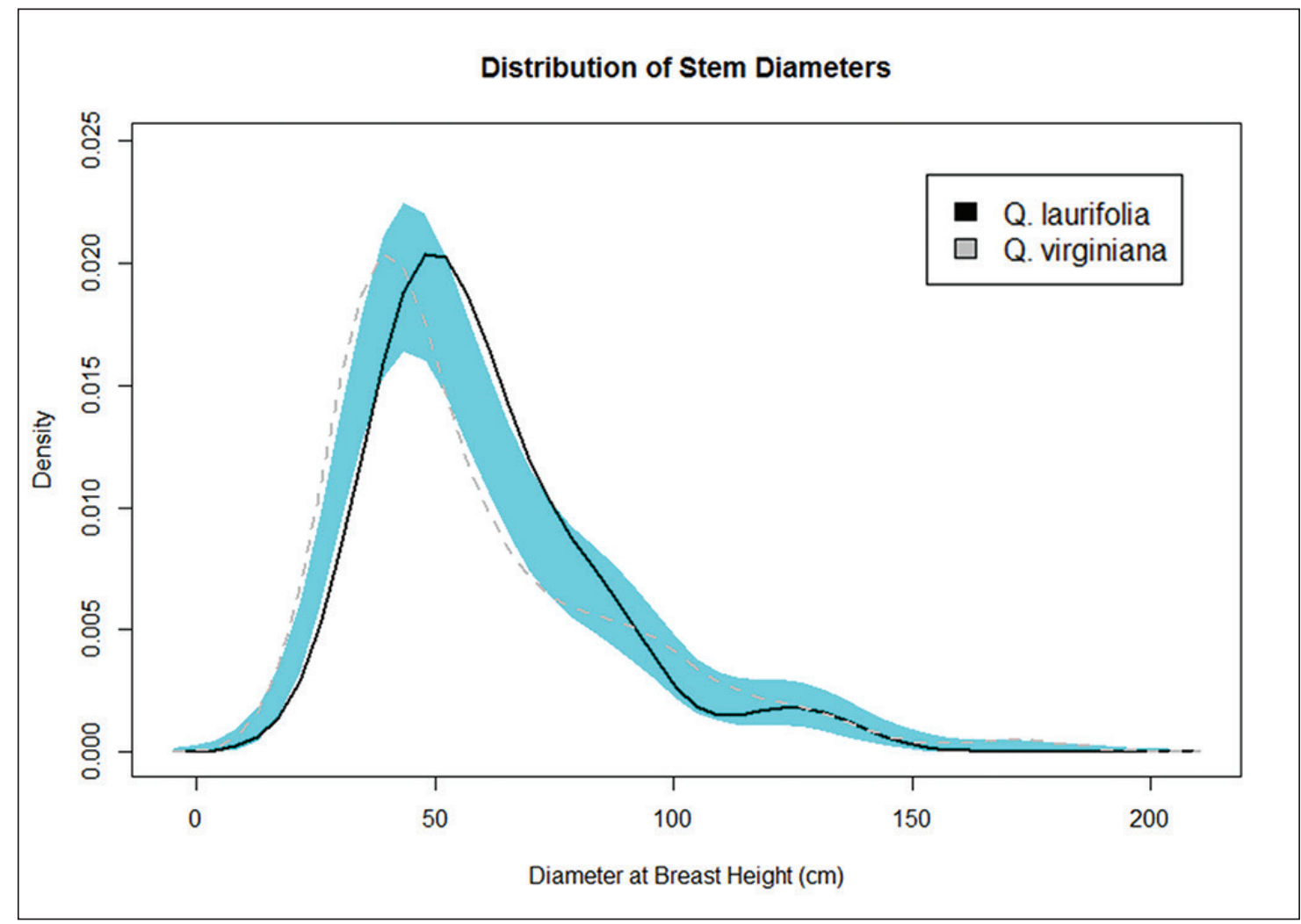

Figure 2. Comparison of probability distributions for measured stem diameters for live (Quercus virginiana) and laurel (Quercus laurifolia) oak trees sampled along Tampa, Florida, U.S., evacuation routes. Sections where the density functions (solid and dashed lines) fall outside of the blue band are areas where the two populations differ.

From a structural stand point, the amount of sound wood along the outer edge of the trunk is of greater interest and was obtainable given the range of the equipment. That said, researchers had originally hoped to quantify decay in order to assess its impact on carbon sequestration models. This question, posed in the concluding remarks by Luley et al. (2009), remains unanswered given the limitations of the current study.

\section{Frequency and Severity of Stem Decay}

Within the larger sample of trees assessed visually, 152 live oak and 86 laurel oak over $30.5 \mathrm{~cm}$ in diameter were also assessed for decay with a resistance-recording drill. Of the laurel oak tested, 58 trees (67.4\%) had decay, as defined as by the decision rule. In contrast, less than one-third (29.4\%) of the live oaks tested had stem decay. This difference in decay severity was picked up in the hypothesis testing of the kernel density plots $(P<$ 0.01 , Figure 3 ) and supports laurel oak's reputation as being a poor compartmentalizer (Kennard et al. 1996). Compared to laurel oak, live oak, a species viewed as being a stronger compartmentalizer (Kampf et al. 2014), had greater numbers of individuals with $100 \%$ measured sound wood. In contrast, laurel oak had more individuals with $55 \%$ to $75 \%$ sound wood and $\approx 40 \%$ sound wood (Figure 3). At the lowest levels of sound-woodto-stem-diameter ratio (less than $30 \%$ ), both species were similar. This likely reflects the active management and removal of street trees in Tampa (as opposed to a more natural system where trees would be allowed to decline to the point of failure).

The overall incidence of decay for the partial population of the two oak species assessed with the resistance-recording drill was $56.9 \%$ $(\mathrm{n}=239)$. A simple test of equal proportions with the prop.test() function in $\mathrm{R}$ ( $\mathrm{R}$ Development Core Team 2014) showed the total observed incidence of decay was statistically similar $(P=0.72)$ to the $58.3 \%(\mathrm{n}=1848)$ incidence of decay observed by Luley et al. (2009) in upstate New York. In their assessment of 
three maple species, Luley et al. (2009) found that $63 \%$ of the sugar maple (Acer saccharum) had decay. This was a higher incidence of decay than was observed with other two species-Norway maple (Acer platanoides; 62\%) and silver maple (Acer saccharinum; 53\%). When comparing the most frequently decayed species for the two studies, the laurel oak in Tampa had a higher frequency of decay than the sugar maple in upstate New York $(P=0.02)$.

\section{Biological Factors/Visual Indicators Associated with Stem Decay}

The logistic regression model indicated that species $(P<0.01)$ and dbh $(P<0.01)$ were significant predictors of the presence/absence of stem decay. According to the final model, a laurel oak in the sample set was more than six times more likely to have decay than a live oak (Table $2)$. Tree diameter also had a significant impact on decay $(P<0.01)$, although its relationship was not strictly linear, as seen with the signifi- cant quadratic $(P<0.01)$ and cubic $(P=0.01)$ terms in the final model. Initially, the likelihood of decay increased with diameter increase. However, as tree diameter increased past $75 \mathrm{~cm}$, the probability of decay plateaued (Figure 4). Again this trend likely reflects the removal or failure of hollow trees as they mature.

From a management perspective, a key finding from this research was the significance of the "visual decay" factor $(P=0.03)$ in predicting internal stem decay. This factor encompassed all the visual indicators of decay as outlined by Pokorny (2003), including fruiting bodies, cavities, bulges, and cracks. The significance of this factor shows visual cues can be effective in identifying decay presence in trees when assessed by a trained arborist. For laurel oak in particular, visual cues were present for nearly all cases where sound wood was less than $60 \%$ (Table $3)$. Visual cues were less common with live oak, but so was decay in general (Table 4).

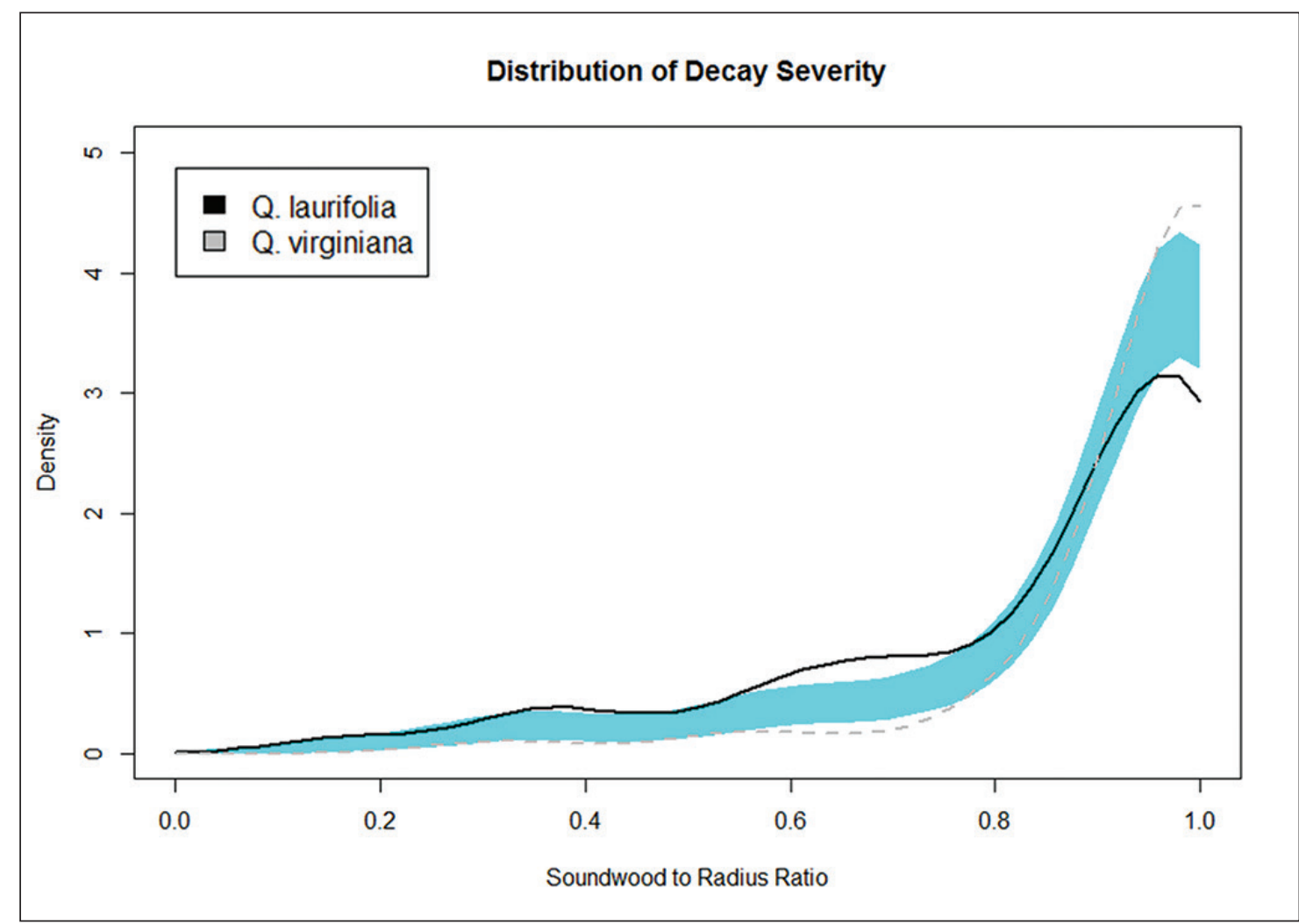

Figure 3. Comparison of probability distributions for measured sound wood in live (Quercus virginiana) and laurel (Quercus laurifolia) oak trees sampled along Tampa, Florida, U.S., evacuation routes. Sections where the density functions (solid and dashed lines) fall outside of the blue band are areas where the two populations differ. 


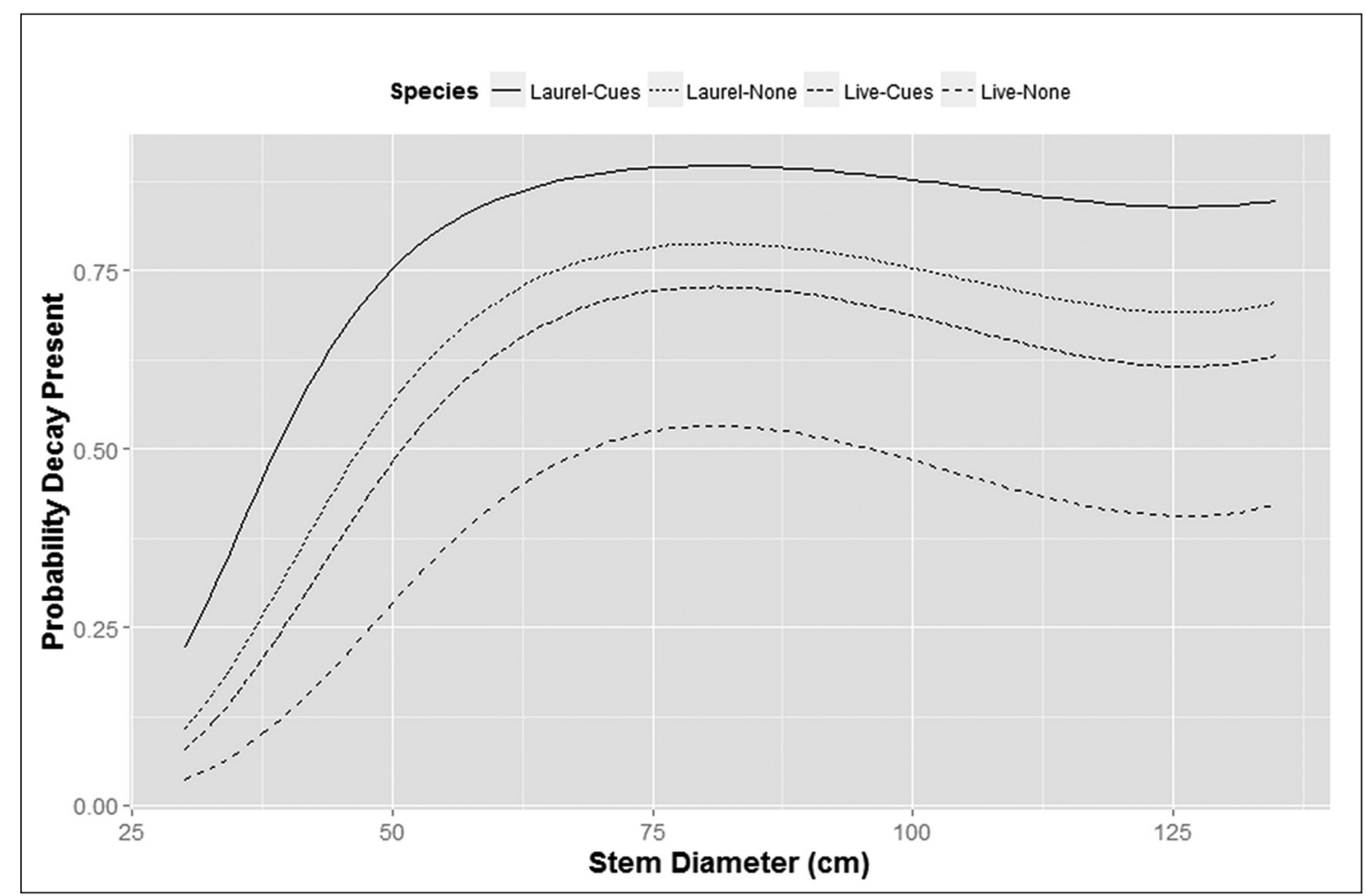

Figure 4. Estimated probability of decay presence in live oak (Quercus virginiana) and laurel oak (Quercus laurifolia) street trees (with or without visual cues of decay) sampled along Tampa, Florida, U.S., hurricane evacuation routes. Estimates computed via logistic regression. Lines (from top of the graph to bottom) represent: laurel oak visual decay cues, laurel oak with no decay cues, live oak with visual decay cues, and live oak with no decay cues.

When collecting potentially subjective datasuch as tree vitality ratings or risk ratingsresearchers used the same arborist technician to limit additional variation that could mask statistical relationships. While the USDA Forest Service risk assessment method used in this study provided a list of standardized and defined visual cues, differing arborists could have greater or lesser predictive success when conducting a visual decay assessment. In a proceedings article from the 2007 ISA Australia Chapter annual meeting, Norris (2007) presented findings from a trial in which 12 experienced arborists inspected trees (representing a range of targets and structural conditions) using eight different risk assessment methods. In comparing their ratings, he found that the evaluations of the arborists varied greatly and attributed the variation to differing attitudes toward risk among the participants (Norris 2007). While recognizing visual cues is arguably less subjective than an actual risk assessment (e.g., a cavity is either present or not), arborists may differ in their ability to spot less obvious decay indicators (e.g., bulges) or survey a tree without omitting portions of it.

The ANSI A300 standard for tree risk assessment (ANSI 2011) specifies three levels of tree risk assessment. All decay-detecting devices are considered part of a Level 3 or advanced assessment (ANSI 2011). Advanced assessment techniques are often the focus of arboricultural research (Rinn et al. 1996; Costello and Quarles 1999; Johnstone et al. 2007; Wang and Allison 2008; Johnstone et al. 2010a; Johnstone et al. 2010b; Arciniegas et al. 2014); however, in the authors' experience, the majority of risk assessments conducted by practicing arborists, urban foresters, and utility vegetation managers rely on visual cues and basic hand tools. While there is surely a place for intensive decay assessment with advanced equipment (e.g., a high-value or historic tree with many possible targets), visual and low-tech assessments can also be effective (Hickman et al. 1995; Kennard et al. 1996).

In a 2005 study, Rooney et al. assessed two levels of visual risk assessment: limited visual (Level 1) 
and basic (Level 2). In this work, researchers found that $90 \%$ of the trees that received the highest risk ratings (i.e., ranked $10-12$ on a 12 -point scale) during the basic walk-by assessment were rated similarly by an arborist performing a limited visual assessment in a moving vehicle. Rooney et al. (2005) saw less agreement between the limited visual and basic assessments as risk rating decreased. This same pattern was seen with the basic and advanced assessments for the laurel oak. Visual decay detection was much more likely as decay severity increased (Table 3 ).

Table 3 and Table 4 show 17 cases where potential or positive decay indicators were present in the laurel and live oak, but no stem decay was found with the resistance-recording drill. While some of these could be false positives, inherent to visual assessment with potential indicators, there were other cases where positive decay indicators were higher up in the tree. While the maximum measurement height limited researchers' assessment of decay to the lower portions of the trunk, this is a portion of the tree that is considered to be most prone to decay given root damage and disruption. (Rinn pers. comm.). This is supported by research from Finland, where researchers noted that $48 \%-76 \%$ of trees (i.e., Tilia spp., Betula spp., Acer spp.) removed from the City of Helsinki had defects (including decay) in the stem, butt, and/or roots (Terho and Hallaksela 2005). In a later assessment of 181 trees, Terho and Hallaksela (2008) generated decay profile plots for the three genera, showing a greater level of decay in the lower sections of Acer spp. and Tilia spp.

\section{CONCLUSION}

This work offers additional insights into the prevalence of stem decay in urban street trees. Although species and climate were different, the incidence of decay in Quercus spp., in Tampa, was similar to incidence of decay reported in the literature by Luley et al. (2009). Beyond addressing this basic question, this work shows that basic visual assessment can be used to effectively assess the presence

Table 3. Comparison of laurel oak (Quercus laurifolia) street trees in Tampa, Florida, U.S., with visual decay indicators and internal stem decay $(n=86)$. Trees were assessed visually prior to advanced assessment with a resistance-recording drill.

\begin{tabular}{|c|c|c|c|}
\hline Decay severity & $\begin{array}{l}\text { Trees with positive/potential } \\
\text { decay indicators }\end{array}$ & $\begin{array}{l}\text { Actual number of trees } \\
\text { with decay at this level }\end{array}$ & $\begin{array}{l}\text { Percent identified correctly } \\
\text { with visual assessment }\end{array}$ \\
\hline $0 \%$ & 10 & 28 & $64.3 \%^{y}$ \\
\hline $1 \%-10 \%$ & 14 & 22 & $63.6 \%$ \\
\hline $11 \%-20 \%$ & 5 & 9 & $55.6 \%$ \\
\hline $21 \%-30 \%$ & 3 & 7 & $42.8 \%$ \\
\hline $31 \%-40 \%$ & 5 & 6 & $83.3 \%$ \\
\hline $41 \%-50 \%$ & 4 & 4 & $100 \%$ \\
\hline $51 \%-60 \%$ & 2 & 3 & $66 \%$ \\
\hline $61 \%-70 \%$ & 5 & 5 & $100 \%$ \\
\hline $71 \%-80 \%$ & 0 & 0 & $\mathrm{n} / \mathrm{a}$ \\
\hline $81 \%-90 \%$ & 2 & 2 & $100 \%$ \\
\hline
\end{tabular}

${ }^{\mathrm{z}}$ Based on resistance-recording drill measurement data.

y To calculate this percentage, researchers compared the number of trees without positive/potential decay indicators (18) to the actually number of trees without decay (28).

Table 4. Comparison of live oak (Quercus virginiana) street trees in Tampa, Florida, U.S., with visual decay indicators and internal stem decay $(n=153)$. Trees were assessed visually prior to advanced assessment with a resistance-recording drill.

\begin{tabular}{|c|c|c|c|}
\hline Decay severity ${ }^{z}$ & $\begin{array}{l}\text { Trees with positive/potential } \\
\text { decay indicators }\end{array}$ & $\begin{array}{l}\text { Actual number of trees } \\
\text { with decay at this level }\end{array}$ & $\begin{array}{l}\text { Percent identified correctly } \\
\text { with visual assessment }\end{array}$ \\
\hline $0 \%$ & 7 & 108 & $93.5 \%{ }^{y}$ \\
\hline $1 \%-10 \%$ & 4 & 18 & $22.2 \%$ \\
\hline $11 \%-20 \%$ & 1 & 16 & $6.3 \%$ \\
\hline $21 \%-30 \%$ & 1 & 3 & $33.3 \%$ \\
\hline $31 \%-40 \%$ & 0 & 2 & $0.0 \%$ \\
\hline $41 \%-50 \%$ & 0 & 3 & $0.0 \%$ \\
\hline $51 \%-60 \%$ & 0 & 0 & $\mathrm{n} / \mathrm{a}$ \\
\hline $61 \%-70 \%$ & 0 & 1 & $0.0 \%$ \\
\hline $71 \%-80 \%$ & 1 & 2 & $50.0 \%$ \\
\hline $81 \%-90 \%$ & 0 & 0 & $\mathrm{n} / \mathrm{a}$ \\
\hline
\end{tabular}

${ }^{\mathrm{z}}$ Based on resistance-recording drill measurement data.

y To calculate this percentage, researchers compared the number of trees without positive/potential decay indicators (101) to the actually number of trees without decay (108). 
of internal stem decay, especially for significantly decayed laurel oak-a species noted for its limited ability to compartmentalize decay. Visual cues were less reliable for live oak, though the species had much lower incidences of decay.

Acknowledgments. This study was supported by a University of Florida Center for Landscape Conservation and Ecology (CLCE) Faculty Enhancement Program Grant. CLCE is a multidisciplinary, statewide center through the Institute of Food and Agricultural Sciences (IFAS) charged with protecting and conserving Florida's natural resources through research-based sustainable urban landscape practices.

\section{LITERATURE CITED}

ANSI. 2011. A300 (Part 9)-2011 Tree Risk Assessment; a. Tree Structure Assessment. Tree Care Industry Association, Inc., Londonderry, New Hampshire, U.S.

Arciniegas, A., F. Prieto, L. Brancheriau, and P. Lasaygues. 2014. Literature review of acoustic and ultrasonic tomography in standing trees. Trees 28:1559-1567.

Bowman, A.W., and A. Azzalini. 2014. R package 'sm': Nonparametric smoothing methods (version 2.2-5.4). Accessed 02 April 2015. <www.stats.gla.ac.uk/ adrian/sm> and <http://azzalini. stat.unipd.it/Book_sm>

Ciftci, C., B. Kane, S.F. Brena, and S.R. Arwade. 2014. Loss of moment capacity of tree stems induced by decay. Trees 28:517-529.

Costello, L.R., and S.L. Quarles. 1999. Detection of wood decay in blue gum and elm: An evaluation of the RESISTOGRAPH ${ }^{\circ}$ and the portable drill. Journal of Arboriculture 25:311-318.

Crawley, M.J., 2013. The R Book, second edition. Wiley, West Sussex, United Kingdom.

Dunster, J., E.T. Smiley, N. Matheny, and S. Lilly. 2013. Tree Risk Assessment-Manual. International Society of Arboriculture, Champaign, Illinois, U.S. 198 pp.

Ellison, E.J., 2005. Quantified tree risk assessment used in the management of amenity trees. Journal of Arboriculture 31:57-65.

Fox, J., and S. Weisberg. 2011. An R Companion to Applied Regression, second edition. SAGE, Thousand Oaks, California, U.S.

Gilbert, E.A., and E.T. Smiley. 2004. PiCUS sonic tomography for the quantification of decay in white oak (Quercus alba) and hickory (Carya spp.). Journal of Arboriculture 30:277-281.

Hickman, G.W., E. Perry, and R. Evans. 1995. Validation of a tree failure evaluation system. Journal of Arboriculture 21:233-234.

Johnstone, D., G. Moore, M. Tausz, and M. Nicolas. 2010a. The measurement of wood decay in landscape trees. Arboriculture \& Urban Forestry 36:121-127.

Johnstone, D., M. Tausz, G. Moore, and M. Nicolas. 2010b. Quantifying wood decay in Sydney bluegum (Eucaluptus saligna) trees. Arboriculture \& Urban Forestry 36:243-252.

Johnstone, D.M., P.K. Ades, G.M. Moore, and I.W. Smith. 2007. Predicting wood decay in eucalypts using an expert system and the IML-Resistograph drill. Arboriculture \& Urban Forestry 36:76-82.

Kampf, E., M.L. Duryea, E.F. Gilman, and A. Delgado. 2014. Assessing hurricane-damaged trees and deciding what to do. FOR711. Gainesville: University of Florida, Institute of Food and Agricultural Sciences. $17 \mathrm{pp}$.
Kennard, D., F. Putz, and M. Neiederhofer. 1996. The predictability of tree decay based on visual assessments. Journal of Arboriculture 22:249-254.

Langlois, T., B.R. Fitzpatrick, D.V. Fairclough, C.B. Wakefield, S.A. Hesp, D.L. McLean, E.S. Harvey, and J.J. Meeuwig. 2012. Similarities between line fishing and baited stereo-video estimations of length-frequency: Novel application of kernel density estimates. PLoS ONE 7:e45973.

Luley, C., D. Nowak, and E. Greenfield. 2009. Frequency and severity of trunk decay in street tree maples in four New York cities. Arboriculture \& Urban Forestry 35:94-99.

Matheny, N., and J. Clark. 1994. A Photographic Guide to the Evaluation of Hazard Trees in Urban Areas, second edition. International Society of Arboriculture, Champaign, Illinois, U.S.

Mattheck, C., K. Bethge, and W. Albrecht. 1997. How to read the results of RESISTOGRAPH ${ }^{\bullet} \mathrm{M}$. Arboricultural Journal 21:331-346.

Norris, M. 2007. Tree risk assessments-What works-What does not-Can we tell? A review of a range of existing tree risk assessment methods. ISAAC Conference. Perth 2007. 29 pp.

Pokorny, J. 2003. Urban Tree Risk Management: A Community Guide to Program Design and Implementation. USDA-FS NATP03-03.

Rinn, F., F.H. Schweingruber, and E. Schär. 1996. RESISTOGRAPH ${ }^{\circ}$ and X-ray density charts of wood comparative evaluation of drill resistance profiles and X-ray density charts of different wood species. Holzforschung 50:303-311.

Rooney, C., H. Ryan, D. Bloniarz, and B. Kane. 2005. The reliability of a windshield survey to locate hazards in roadside trees. Journal of Arboriculture 31:89-94.

Sheather, S. 2010. A Modern Approach to Regression with R. Springer, New York, U.S. pp. 263-293.

Smiley, E.T., N. Matheny, and S. Lilly. 2011. Best Management Practices: Tree Risk Assessment. International Society of Arboriculture, Champaign, Illinois, U.S. 81 pp.

Tate, R.L. 1984. Stem decay in Central Park. Journal of Arboriculture. 10:307-308.

Tate, R.L. 1986. Stem decay in street trees in New Jersey and park trees in Central Park, New York. Journal of Arboriculture 12:73-74.

Terho, M., and A. Hallaksela. 2005. Potential hazard characteristics of Tilia, Betula, and Acer trees removed in the Helsinki city area during 2001-2003. Urban Forestry \& Urban Greening 3: 113-120.

Terho, M., and A.M. Hallaksela. 2008. Decay characteristics of hazardous Tilia, Betula, and Acer trees felled by municipal urban tree managers in the Helsinki City Area. Forestry 81:151-159.

Wang, X., and R.B. Allison. 2008. Decay detection in red oak trees using a combination of visual inspection, acoustic testing, and resistance microdrilling. Arboriculture \& Urban Forestry 34:1-4.

Wilcox, W. 1978. Review of literature on the effects of early stages of decay on wood strength. Wood Fiber 9:252-257. 


\author{
Andrew K. Koeser (corresponding author) \\ Assistant Professor \\ Department of Environmental Horticulture, CLCE, IFAS \\ University of Florida - Gulf Coast Research and Education \\ Center \\ 14625 County Road 672 \\ Wimauma, Florida 33598, U.S. \\ akoeser@ufl.edu \\ Drew C. McLean \\ Biological Scientist \\ Department of Environmental Horticulture, CLCE, IFAS \\ University of Florida - Gulf Coast Research and Education \\ Center \\ 14625 County Road 672 \\ Wimauma, Florida 33598, U.S. \\ Gitta Hasing \\ Senior Biological Scientist \\ Department of Environmental Horticulture, CLCE, IFAS \\ University of Florida - Gulf Coast Research and Education \\ Center \\ 14625 County Road 672 \\ Wimauma, Florida 33598, U.S. \\ R. Bruce Allison \\ Board Certified Master Arborist \\ Allison Tree Care, LLC \\ 1830 Sugar River Road, Verona, Wisconsin 53593, U.S. \\ Adjunct Professor \\ Department of Forest and Wildlife Ecology \\ University of Wisconsin-Madison \\ 1630 Linden Drive, Madison, Wisconsin 53706-1598, U.S.
}

Résumé. La carie du bois est un facteur pris en compte dans toutes les méthodes, communément acceptées, d'évaluation des risques liés aux arbres; cependant, peu d'études ont tenté d'estimer sa présence dans une forêt urbaine ou sa prévisibilité en fonction des signes visuels et des facteurs de site. Un échantillonnage aléatoire d'arbres situés dans des couloirs d'évacuation des populations lors d'ouragans ont été inventoriés et évalués en fonction des risques présentés dans la ville de Tampa en Floride, États-Unis. En plus d'une évaluation visuelle de base, un échantillonnage de chênes de Virginie (Quercus virginiana) de gros diamètre $(>30,5 \mathrm{~cm}$ ) et tous les gros chênes de Laurier (Quercus laurifolia) ont été évalués avec une perceuse mesurant la résistance afin de déterminer l'importance de la carie présente (en regardant spécifiquement le rapport bois sain / diamètre de la tige). Dans l'ensemble, 56,9\% des arbres évalués présentaient un certain niveau de carie, bien que l'incidence de la carie ait été plus élevée chez les chênes de Laurier $(67,4 \%)$ que chez les chênes de Virginie (29,4 \%). En outre, l'essence $(P<0,01)$, le diamètre $(P<0,01)$ et la présence ou l'absence de signes visuels indicateurs de carie $(P=0,03)$ étaient tous des indices significatifs de la présence de carie.

Zusammenfassung. In allen gemeinhin akzeptierten Methoden der Abschätzung des Baumrisikos wird der Holzabbau durch Fäule als Faktor berücksichtigt. Dennoch haben nur wenige Studien bislang versucht, die Gegenwärtigkeit in urbanen Forstbeständen zu untersuchen oder die Vorhersehbarkeit durch visuelle Anzeichen und Standortfaktoren zu bestimmen. Von einer zufälligen Auswahl von Bäumen, die entlang einer Wirbelsturmroute in der Stadt Tampa, Florida, U.S., ihren Standort haben, wurde Daten erhoben und das Versagensrisiko bewertet. Zusätzlich zu einer grundsätzlichen Sichtkontrolle wurden Proben von Lebenseichen mit von größeren Durchmessern $(>30.5 \mathrm{~cm})$ und alle großen Lorbeereichen mit einem Resistographen getestet, um das Ausmaß an vorhandener Fäule (mit besonderem Blick auf das Verhältnis von gesundem $\mathrm{Holz}$ zu Stammdurchmesser) zu bestimmen. Im Ganzen hatten 56,9 \% der getesteten Bäume Anzeichen von Fäulnis, obwohl die Indizien für Fäulnis bei den Lorbeereichen größer(67.4\%) war als bei den Lebenseichen (29.4\%). Zusätzlich waren die Baumart $(P<0.01)$, der Durchmesser $(P<0.01)$ und die Präsenz oder Abwesenheit von sichtbaren Fäulnisanzeichen $(P=0.03)$ bedeutsame Vorhersagekriterien für die vorhandene Fäulnis.

Resumen. La descomposición de la madera es un factor considerado en todos los métodos de evaluación de riesgo del árbol comúnmente aceptados. Sin embargo, pocos estudios han intentado evaluar su presencia en el bosque urbano o su previsibilidad dando señales visuales y factores del sitio. Un muestreo aleatorio de los árboles situados en las rutas de evacuación de huracanes fue inventariado y evaluado para el riesgo en la ciudad de Tampa, Florida, EE.UU. Además de una evaluación visual básica, una muestra de mayor diámetro (> $30,5 \mathrm{~cm}$ ) de roble (Quercus virginiana) y todas los diámetros grandes de roble laurel (Quercus laurifolia) fueron analizados con una prueba de resistencia para determinar la cantidad de descomposición presente (centrándose específicamente en la relación madera sana - diámetro). En general, 56,9\% de los árboles ensayados tenía algún nivel de decaimiento, aunque la incidencia de la descomposición fue mayor en roble laurel $(67,4 \%)$ que en el roble vivo $(29,4 \%)$. Además, las especies de árboles $(\mathrm{P}<0,01)$, diámetro $(\mathrm{P}<0,01)$ y la presencia $\mathrm{o}$ ausencia de indicadores visuales de descomposición $(\mathrm{P}=0,03)$ fueron todos predictores significativos de la presencia de descomposición. 